\title{
PENGARUH DIMENSI DIMENSI IKLIM ORGANISASI TERHADAP KINERJA PEGAWAI DI BADAN KEPEGAWAIAN DAERAH PROVINSI NUSA TENGGARA BARAT
}

\author{
Muhammad Amri Fuadi ${ }^{1}$, Hermanto ${ }^{2}$, Lalu Suparman ${ }^{3}$ \\ ${ }^{1}$ Magister Manajemen Fakultas Ekonomi dan Bisnis, Universitas Mataram \\ E-mail: dfuady@gmail.com \\ 2,3Fakultas Ekonomi dan Bisnis, Universitas Mataram
}

\begin{abstract}
ARTICLE INFO
Keywords :

Organizational Climate Dimensions and Employee Performance Dimensions.
\end{abstract}

\section{Kata Kunci :}

Dimensi Iklim Organisasi dan Dimensi Kinerja Pegawai.

How to cite :

Amri Fuadi, Muhammad., Hermanto., Suparman, Lalu., (2019). Pengaruh Dimensi Dimensi Iklim Organisasi Terhadap Kinerja Pegawai Di Badan Kepegawaian Daerah Provinsi Nusa Tenggara Barat, 9(1), 1-12

DOI :

http://dx.doi.org/10.29303/jmm.v9i1.475

Dikumpulkan : 23 Agustus 2019

Direvisi :28 Agustus 2019

Dipublikasi : :02 September 2019

\section{ABSTRACT}

This research is directed to prove the significance of the influence of organizational climate dimensions in the form of physical environment (X1), social environment (X2) and management system (X3) on the dimensions of employee performance in the form of employee work goals (Y1) and employee work behavior (PKP). There are six hypotheses that are proven through a partial least square (PLS) analysis process. The population of this study (observation data) was 82 BKD NTB employees. Data was collected through questionnaires and all questionnaires returned in accordance with data input needs. Through the outer model stage there are two indicators of the social environment that are issued, namely the relationship of superiors with subordinates (LS1) and colleague relations (LS2) as well as two indicators of employee work behavior, namely commitment (PKP3) and leadership (PKP6). Indicators that are classified as valid get a reinforcement of criteria through the parameter AVE values above 0.50 and include reliable indicators through Cronbach's alpha parameters and composite reliability above 0.70. PLS analysis through the inner model stage found that all dimensions of the organization's climate have a positive influence (positive sign of the path coefficient) on the dimensions of employee performance.

Penelitian ini diarahkan untuk membuktikan signifikansi pengaruh dari dimensi iklim organisasi berupa lingkungan fisik $\left(X_{1}\right)$, lingkungan sosial $\left(X_{2}\right)$ dan sistem manajemen $\left(X_{3}\right)$ terhadap dimensi kinerja pegawai berupa sasaran kerja pegawai $\left(\mathrm{Y}_{1}\right)$ dan perilaku kerja pegawai (PKP). Terdapat enam hipotesis yang dibuktikan melalui proses analisis partial least square (PLS). Populasi penelitian ini (data observasi) sebanyak 82 orang pegawai BKD Provinsi NTB. Data dikumpulkan melalui penyebaran angket dan seluruh angket kembali sesuai dengan kebutuhan input data. Melalui tahap outer model terdapat dua indikator lingkungan sosial yang 


\section{Jurnal Magister Manajemen Unram Vol. 9, No 1. Maret 2020 NATIONALLY ACCREDITED JOURNAL - DECREE NO. 21/E/KPT/2018}

\begin{tabular}{|l|l|l|}
\hline & $\begin{array}{l}\text { dikeluarkan, yaitu hubungan atasan dengan bawahan } \\
\left(\mathrm{LS} \mathrm{S}_{1} \text { dan hubungan rekan kerja }\left(\mathrm{LS}_{2}\right) \text { serta dua indikator }\right. \\
\text { dari perilaku kerja pegawai, yaitu komitmen }\left(\mathrm{PKP}_{3}\right) \text { dan } \\
\text { kepemimpinan }\left(\mathrm{PKP}_{6}\right) \text {. Indikator yang tergolong valid } \\
\text { mendapatkan penguatan kriteria melalui parameter nilai } \\
\text { AVE di atas 0,50 serta termasuk indikator yang reliabel } \\
\text { melalui parameter alpha Cronbach serta composite } \\
\text { reliability di atas 0,70. Analisis PLS melalui tahap inner } \\
\text { model ditemukan bahwa seluruh dimensi iklim } \\
\text { organisasi memberikan pengaruh positif (tanda positif } \\
\text { dari koefisien jalur) terhadap dimensi kinerja pegawai. }\end{array}$ \\
$\begin{array}{l}\text { Copyright } \\
\text { reserved. }\end{array}$ \\
\hline
\end{tabular}

\section{PENDAHULUAN}

Keberaadaan aparatur sipil negara (ASN) sangat penting dalam mempercepat realisasi tujuan bernegara, termasuk di tingkat regional. Direalisasikan melalui pelaksanaan fungsi ASN berupa pelaksana kebijakan publik dan pelayan publik (pasal 10 UU No. 5 Tahun 2014 tentang Aparatur Sipil Negara). Peningkatan kemampuan menjalankan fungsi tersebut sangat relevan dengan peningkatan profesionalitas para ASN. Pengembangan tersebut dilakukan secara mandiri pegawai, internal organisasi dan hasil kerja organisasi publik, yaitu Badan Kepegawaian Daerah (BKD). BKD mempunyai salah satu fungsi merencanakan dan mengembangkan manajemen kepegawaian daerah, termasuk di lingkup pemerintahan Provinsi NTB.

Kinerja BKD pada dasarnya adalah mengembangkan ASN pada organisasi publik lainnya. Kinerja bukan sebatas kemampuan menyelesaikan tugas, tetapi harus bermakna dalam merealisasikan hasil (outcome). Kinerja adalah "catatan mengenai outcome yang dihasilkan dari suatu aktivitas tertentu, selama kurun waktu tertentu pula" (Russell, dkk., dalam Sedarmayanti, 2007:260). Konsep kinerja pada ASN secara individual ataupun secara organisasi harus mengalami perkembangan. Pengukurannya bukan sebagai rutinitas, tetapi dijadikan dasar untuk membuat kebijakan kembali dalam meningkatkan kinerja individu ASN dan organisasi. Di Indonesia pengukuran kinerja ASN melalui dua dimensi, yaitu dimensi sasaran kerja pegawai (SKP) dan perilaku kerja pegawai (PKP). SKP berhubungan dengan rencana kerja dan target yang akan dicapai oleh pegawai, diukur dengan kuantitas, kualitas, waktu dan biaya dalam realisasi kerja. Adapun dimensi perilaku kerja terkait dengan tingkah laku, sikap, atau tindakan yang dilakukan oleh PNS sesuai dengan ketentuan perundangan, diukur dengan orientasi pelayanan, integritas, komitmen, disiplin, kerja sama dan kepemimpinan (pasal 12 PP No. 46 Tahun 2011).

Pengelola ASN perlu mengetahui faktor penjelas yang mempengaruhi kinerja, terutama melalui dimensinya. Secara teoritis terdapat banyak faktor yang mempengaruhi kinerja. Robbins (2003 : 232) merumuskan model kinerja sebagai performance $=\mathrm{f}$ (ability, motivation, opportunity). Gibson, et al. (1997 : 124) mengidentifikasikannya berupa lingkungan kerja (desain pekerjaan, struktur organisasi, kebijakan dan aturan, kepemimpinan, penghargaan dan sanksi serta sumber daya) dan faktor individu (kemampuan dan keterampilan, latar belakang keluarga, kepribadian, persepsi, sikap, ciri, kapasitas belajar, umur, ras, jenis kelamin serta pengalaman). Deninson dalam Wirawan (2007 : 122) menghasilkan model yang fokus mempengaruhi kinerja melalui pengelolaan dimensi iklim organisasi, yaitu lingkungan fisik, lingkungan sosial dan sistem manajemen. 


\section{Jurnal Magister Manajemen Unram Vol. 9, No 1. Maret 2020 NATIONALLY ACCREDITED JOURNAL - DECREE NO. 21/E/KPT/2018}

Kajian pada BKD Provinsi NTB sangat diperlukan, terkait dengan pengelolaan iklim organisasi terhadap kinerja. Ada nuansa baru di kantor baru dan sisi lain ada beberapa masalah kepegawaian yang berulang, sehingga tidak menunjukkan sisi hasil dari capain kerja pegawai BKD Provinsi NTB. Kajian faktor internal dalam renstra BKD Provinsi NTB masih ditemukan masih belum optimal pada aspek pelayanan, pengembangan dan pembinaan aparatur serta administrasi dan ketepatan informasi.

\section{RUMUSAN MASALAH}

Terdapat enam permasalahan yang diajukan, yaitu 1) signifikansi pengaruh dari lingkungan fisik terhadap sasaran kerja pegawai BKD Provinsi NTB; 2) signifikansi pengaruh dari lingkungan fisik terhadap perilaku kerja pegawai BKD Provinsi NTB; 3) signifikansi pengaruh dari lingkungan lingkungan sosial terhadap sasaran kerja pegawai BKD Provinsi NTB; 4) signifikansi pengaruh dari lingkungan lingkungan sosial terhadap perilaku kerja pegawai BKD Provinsi NTB; 5) signifikansi pengaruh dari lingkungan sistem manajemen terhadap sasaran kerja pegawai BKD Provinsi NTB; serta 6) signifikansi pengaruh dari lingkungan sistem manajemen terhadap perilaku kerja pegawai BKD Provinsi NTB.

\section{TINJAUAN PUSTAKA}

L. Suparman, dkk (2018) dalam penelitiannya menemukan bahwa faktor iklim organisasi berpengaruh signifikan terhadap perilaku kerja fasilitator Program Nasional Pemberdayaan Masyarakat (PNPM) di Pulau Lombok. Iklim organisasi diukur dengan kejelasan tugas dan tanggung jawab, kejelasan proses dan target pelayanan, harmonisasi hubungan, interaksi sosial dengan komunitas target, ketersediaan fasilitas dan perlengkapan kerja serta distribusi dan alokasi sumber daya. Indikator iklim organisasi tersebut akan dikaji secara lebih spesifik dengan mengelompokkannya pada tiga dimensi, berupa lingkungan fisik, lingkungan sosial dan sistem manajemen. Alat analisis yang digunakan sama, yaitu analisis partial least square (PLS), sehingga hasil penelitian tersebut dapat dirujuk.

Mahadevan dan Li (2017) mengidentifikasi tujuh iklim organisasi atas tujuh variabel laten berupa kejelasan peran, komunikasi, sistem reward, kerja tim, pengembangan karir, pengawasan dan hubungan. Dianalisis pengaruhnya secara parsial terhadap kinerja pegawai pada perusahaan konsultan di Malaysia. Ditemukan hanya dimensi hubungan, kerja tim dan pengawasan yang berpengaruh signifikan secara parsial terhadap kinerja pegawai.

Gathmyr (2107) menemukan bahwa iklim organisasi tidak berpengaruh terhadap kinerja, tetapi berpengaruh signifikan dan positif terhadap komitmen para perwira penerbang TNI AU Skadron 31 Pangkalan Udara Halim Perdanakusuma Jakarta. Hasil penelitian masih menunjukkan variasi, sehingga perlu dilakukan penelitian yang mendalam pada setiap organisasi, termasuk pada organisasi publik untuk dapat dikelola guna meningkatkan kinerja pegawai. Penelitian ini fokus menggunakan model Deninson dalam Wirawan (2007:125), dapat dinyatakan sebagai pembuktian atas model tersebut berlaku atau tidak sebagai faktor penjelas untuk meningkat kinerjanya. Variasi penelitian diberikan pada pengukuran kinerja menggunakan dimensi sasaran kerja pegawai dan perilaku kerja pegawai (pasal 12 PP No. 46 Tahun 2011).

Iklim organisasi sebagai persepsi dari anggota organisasi (pegawai) terhadap kualitas lingkungan internal organisasi yang memberikan dampak terhadap perilakunya (Lussier 


\section{Jurnal Magister Manajemen Unram Vol. 9, No 1. Maret 2020 NATIONALLY ACCREDITED JOURNAL - DECREE NO. 21/E/KPT/2018}

dalam Kristanto, dkk., 2018). Simamora (2004:81) memaknai iklim organisasi sebagai faktor psikologi organisasi. Hal tersebut kembali pada istilah awal dari munculnya iklim organisasi berupa iklim psikologi. Iklim organisasi merupakan faktor penting untuk dikelola, karena dapat memberikan dampak pada kreativitas, perilaku, kinerja individual, selanjutnya berdampak pada kinerja organisasi (Deninson dalam Wirawan, 2007:125).

Iklim organisasi dirumuskan dalam tiga dimensi, yaitu lingkungan fisik, lingkungan sosial dan sistem manajemen. Lingkungan fisik diukur dengan kenyamanan tempat kerja $\left(\mathrm{LF}_{1}\right)$, kecukupan ruang kerja $\left(\mathrm{LF}_{2}\right)$, kecukupan peralatan kerja $\left(\mathrm{LF}_{3}\right)$, kesesuaian peralatan kerja $\left(\mathrm{LF}_{4}\right)$ dan kejelasan pedoman proses kerja $\left(\mathrm{LF}_{5}\right)$. Lingkungan sosial diukur dengan hubungan atasan dan bawahan ( $\left.\mathrm{LS}_{1}\right)$, hubungan rekan kerja $\left(\mathrm{LS}_{2}\right)$, kebersamaan $\left(\mathrm{LS}_{3}\right)$, penghargaan atas kreativitas (LS $\left.\mathrm{LS}_{4}\right)$ dan saling mempercayai $\left(\mathrm{LS}_{5}\right)$. Sistem manajemen diukur dengan sistem birokrasi organisasi $\left(\mathrm{SM}_{1}\right)$, proses pengambilan keputusan $\left(\mathrm{SM}_{2}\right)$, alokasi sumber daya $\left(\mathrm{SM}_{3}\right)$, sistem imbalan $\left(\mathrm{SM}_{4}\right)$ dan pengembangan karir $\left(\mathrm{SM}_{5}\right)$. Indikator dari tiga dimensi iklim organisasi tersebut mengacu pada Deninson dalam Wirawan (2007:125).

Cooper dalam Samsudin (2006:159) mendefinisikan kinerja atau prestasi kerja sebagai "tingkat pelaksanaan tugas yang dapat dicapai oleh seseorang, unit, divisi dengan menggunakan kemampuan dan batasan-batasan yang telah ditetapkan untuk mencapai tujuan organisasi". Robbins dan Judge (2008:313) memberikan pernyataan atas kinerja bukan sebatas hasil kerja, tetapi juga meliputi perilaku dan sikap. Relevan dengan makna prestasi kerja khusus untuk PNS, yaitu "hasil kerja yang dicapai oleh setiap PNS pada satuan organisasi sesuai dengan sasaran kerja pegawai dan perilaku kerja" (ayat 3 pasal 1 PP No. 46 tahun 2011 tentang Penilaian Prestasi Kerja Pegawai Negeri Sipil).

Ada kinerja pegawai, yaitu sasaran kerja pegawai (SKP) dan perilaku kerja pegawai (PKP). SKP diukur dengan kuantitas $\left(\mathrm{SKP}_{1}\right)$, kualitas $\left(\mathrm{SKP}_{2}\right)$, biaya $\left(\mathrm{SKP}_{3}\right)$ dan waktu $\left(\mathrm{SKP}_{4}\right)$ dalam penyelesaian setiap pekerjaannya. PKP diukur dengan orientasi pelayanan $\left(\mathrm{PKP}_{1}\right)$, integritas $\left(\mathrm{PKP}_{2}\right)$, komitmen $\left(\mathrm{PKP}_{3}\right)$, disiplin $\left(\mathrm{PKP}_{4}\right)$, kerjasama $\left(\mathrm{PKP}_{5}\right)$ dan kepemimpinan $\left(\mathrm{PKP}_{6}\right)$. Indikator-indikator dari dimensi SKP dan PKP mengacu pada PP No. 45 Tahun 2011.

Kajian dalam penelitian ini bersifat spesifik, karena pengaruh dari iklim organisasi terhadap kinerja pegawai, dianalisis secara mendalam melalui membangun model pengaruh per dimensi dari iklim organisasi terhadap kinerja. Ditampilkan dalam model berikut.

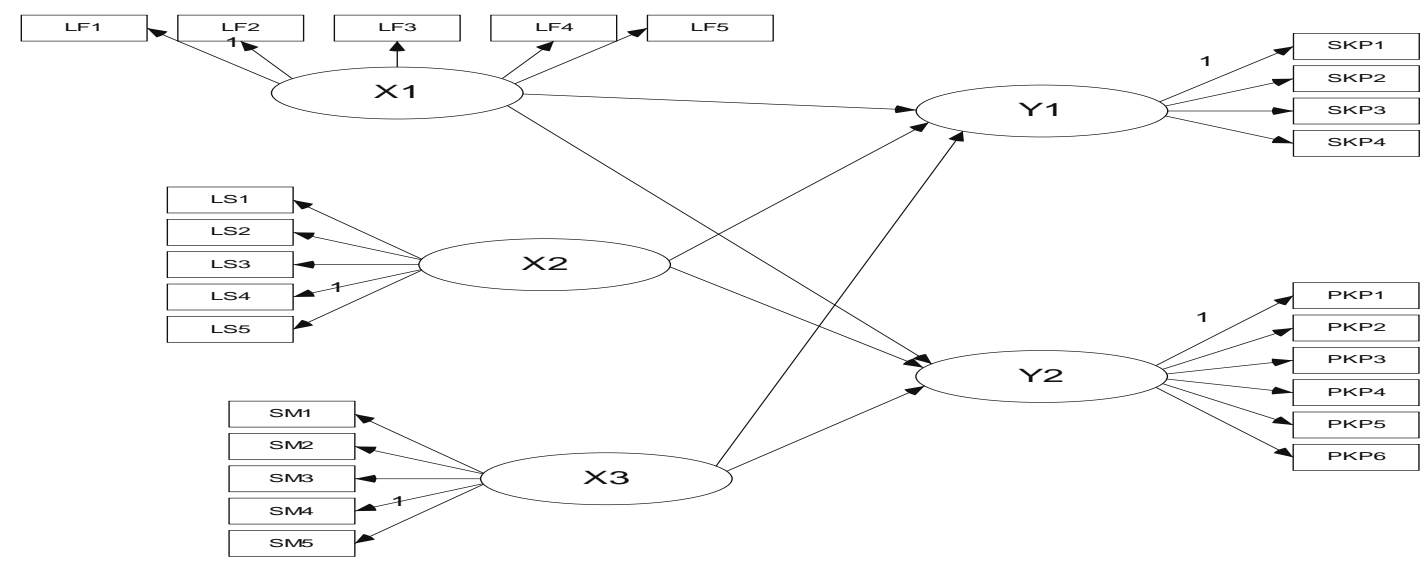

Gambar 1. Model Kerangka Konseptual Penelitian 


\section{Jurnal Magister Manajemen Unram Vol. 9, No 1. Maret 2020 NATIONALLY ACCREDITED JOURNAL - DECREE NO. 21/E/KPT/2018}

\section{METODE PENELITIAN}

Desain penelitian ini adalah penelitian asosiatif, di mana model yang dibangun bersifat struktural (terdiri atas dua variabel tujuan, yaitu sasaran kerja pegawai dan perilaku pegawai sebagai dimensi dari kinerja). Model struktural dibangun dengan partial least square (PLS), sebagai bentuk analisis struktural berbasis statistik non parameterik yang tidak mensyaratkan normalitas residual variabel serta skala tertentu dari variabel (Ghozali, 2008). Data observasi berupa pegawai Badan Kepegawaian Daerah (BKD) Provinsi NTB sebanyak 82 orang (data observasi/n=82). Jumlah seluruh data observasi yang direncanakan (sensus dari aspek jumlah seluruh pegawai, 82 orang) terhimpun dari angket yang disebarkan.

Item setiap dimensi (variabel laten) diukur dengan skala Likert lima ketuk (skor 1-5), digunakan sebagai dasar memberikan uraian setiap item dan variabel serta input data untuk membangun model struktural melalui analisis PLS. Tahap dalam analisis PLS terdiri atas 1) membangun inner model; 2) membangun outer model; 3) membangun diagram jalur; 4) membangun persamaan; 5) estimasi koefisien jalur; 6) evaluasi goodness of fit model; 7) uji hipotesis.

\section{PEMBAHASAN}

Pegawai BKD Provinsi NTB sebagai subyek dalam penelitian ini, secara umum tergolong produktif, dengan rata-rata umur 42,37 tahun. Kesenjangan umur tersebut tergolong tinggi, sebesar 29 tahun, dengan kisaran umur 27-56 tahun. Variasi umur ini juga memberikan kilasan pengalaman, ada yang berpengalaman tinggi dan rendah. Kondisi social learning antar pegawai sangat diperlukan, di mana pegawai senior memberikan bantuan dari aspek pengalaman dan sisi lain pegawai muda dengan ciri kemampuan menyerap perubahan teknologi.

Aspek lain yang perlu diinformasikan adalah tingkat pendidikan para pegawai. Secara akumulatif, pendidikan sarjana strata satu dan dua mempunyai persentase tertinggi, sebanyak 70,73\%. Pendidikan SMA sebanyak 26,83\% dan sisanya sebanyak 2,44\% berpendidikan diploma. Diharapkan dengan pendidikan yang tergolong tinggi ini menjadi stimulan positif para pegawai dalam menjalankan fungsi yang diemban serta aspek lainnya yang mampu menggerakkan kinerjanya.

Mengacu pada angket yang disebarkan, berisikan indikator dari dimensi lingkungan fisik, lingkungan sosial dan sistem manajemen pada para pegawai serta isian kinerja dari penilai dapat dijadikan dasar dalam memberikan uraian atas variabel-variabel laten tersebut. Variabel akan dideskripsikan hanya atas dasar item atau pengukuran yang layak saja. Berdasarkan hasil analisis tahap pembentukan outer model (measurement analysis), sebanyak tiga tahap ditemukan empat item yang tidak layak (memiliki nilai $r$ hitung lebih kecil dari $\mathrm{r}$ tabel atau $\mathrm{p}$ value lebih besar dari 0,05). Item yang tidak valid tersebut berupa $\mathrm{LS}_{1}$ (hubungan atasan dan bawahan; $\mathrm{p}$ value 0,098), $\mathrm{LS}_{2}$ (hubungan rekan kerja, $\mathrm{p}$ value 0,077), $\mathrm{PKP}_{3}$ (komitmen; $\mathrm{p}$ value 0,332) dan $\mathrm{PKP}_{6}$ (kepemimpinan; $\mathrm{p}$ value 0,066 ).

Kriteria penilaian setiap variabel berdasarkan hasil penilaian responden dari angket yang disebar, dengan ketentuan item yang valid saja, sebagai berikut. 
Tabel 1.

Kriteria Dimensi Iklim Organisasi dan Kinerja Pegawai BKD Provinsi NTB Tahun 2019

\begin{tabular}{|c|l|c|c|}
\hline No. & \multicolumn{1}{|c|}{ Variabel } & Rata-rata Skor & Kriteria \\
\hline 1. & Lingkungan fisik $\left(\mathrm{X}_{1}\right)$ & 3,36 & Sedang \\
\hline 2. & Lingkungan sosial $\left(\mathrm{X}_{2}\right)$ & 3,48 & Baik \\
\hline 3. & Sistem manajemen $\left(\mathrm{X}_{3}\right)$ & 3,46 & Baik \\
\hline 4. & Sasaran kerja pegawai $\left(\mathrm{Y}_{1}\right)$ & 3,60 & Tinggi \\
\hline 5. & Perilaku kerja pegawai $\left(\mathrm{Y}_{2}\right)$ & 3,45 & Tinggi \\
\hline
\end{tabular}

Penskoran dengan interval 1-5, sehingga rata-rata skor maksimal sebesar 5,0; dengan interval tertinggi 4,20-5,00. Kriteria tinggi pada lingkungan sosial, sistem manajemen, pencapaian sasaran kerja pegawai dan perilaku kerja masih berada pada tahap awal dari interval dengan kriteria tinggi $(3,40-<34,20)$. Temuan ini memberikan indikasi jelas bahwa variabel tujuan masih belum maksimal dan variabel penjelas masih sangat memungkinkan untuk ditingkatkan kembali. Kondisi iklim organisasi BKD Provinsi NTB secara umum telah muncul sebagai potensi untuk menciptakan kinerja tinggi.

Berdasarkan perundangan penilaian kinerja ASN, bobot untuk SKP sebesar 60,00\% dan PKP sebesar 40,00\%, maka dapat ditentukan kriteria kinerja pegawai BKD Provinsi NTB secara umum. Ditemukan kriteria sangat tinggi sebanyak 9,75\%, kriteria tinggi sebanyak 53,66\% dan kriteria sedang, sebanyak 36,59\%. Temuan ini memperkuat bahwa masih diperlukan upaya-upaya dalam mengelola faktor-faktor yang meningkatkan kinerja, baik melalui dimensi SKP ataupun PKP.

Model struktural dari dimensi iklim organisasi terhadap kinerja pegawai BKD Provinsi NTB digambarkan pada Gambar 2. Model tersebut menjelaskan bahwa tiga dimensi iklim organisasi masing-masing memberikan pengaruh positif terhadap kinerja pegawai BKD Provinsi NTB. Hal tersebut dilihat dari tanda positif koefisien jalurnya. Artinya semakin baik dimensi iklim organisasi dikelola akan memberikan peningkatan pencapaian SKP dan PKP pegawai BKD Provinsi NTB.

Gambar 2.

Model Pengaruh Dimensi Iklim Organisasi terhadap Kinerja Pegawai BKD Provinsi NTB

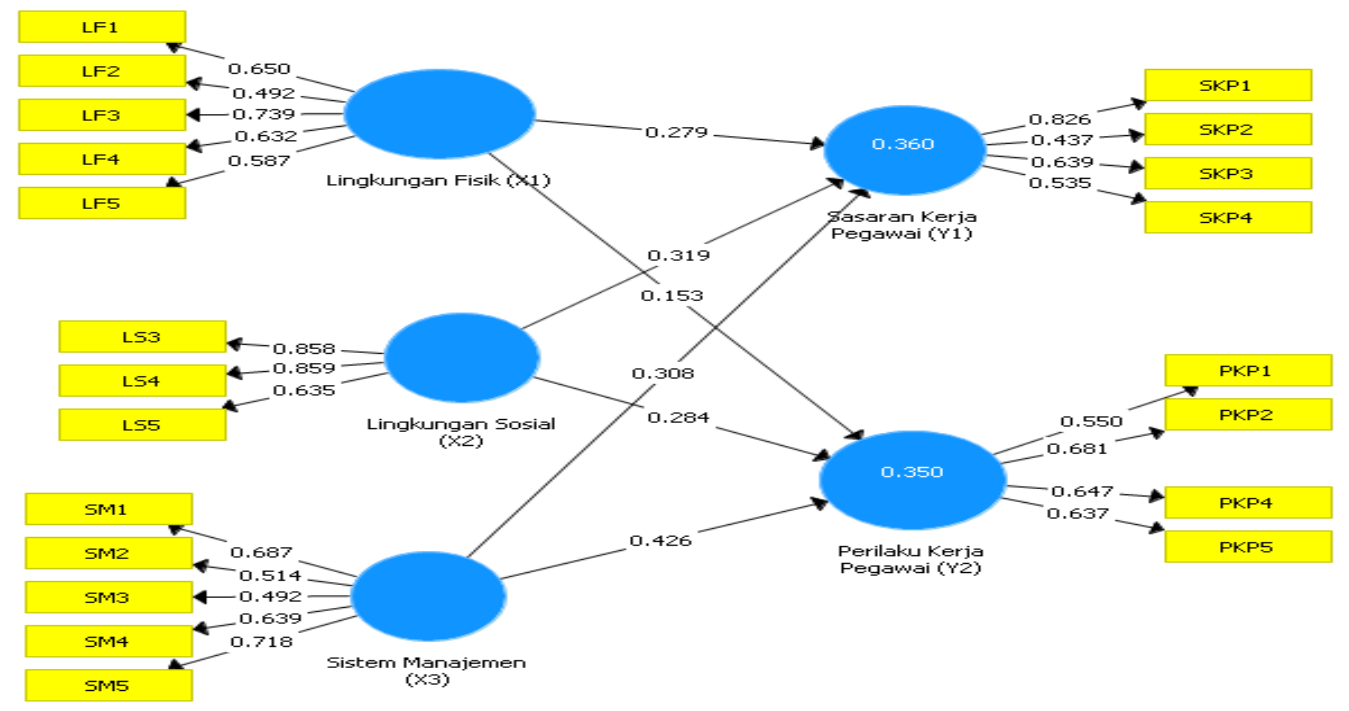

Model di atas, baik dalam konteks outer model ataupun inner model memenuhi kriteria goodness. Nilai koefisien alpha Cronbach, composite reliability serta nilai AVE menunjukkan kriteria reliabel. Adapun goodness of fit model menggunakan nilai koefisien 


\section{Jurnal Magister Manajemen Unram Vol. 9, No 1. Maret 2020 NATIONALLY ACCREDITED JOURNAL - DECREE NO. 21/E/KPT/2018}

determinasi $\left(\mathrm{R}^{2}\right)$ menunjukkan nilai yang cukup tinggi, sebesar 36,00\% untuk persamaan $Y_{1}=f\left(X_{1}, X_{2}, X_{3}\right)$ dan sebesar $35,00 \%$ untuk persamaan $Y_{2}=f\left(X_{1}, X_{2}, X_{3}\right)$. Kompleksnya variabel yang mempengaruhi kinerja, maka dapat dinyatakan bahwa pegaruh yang diberikan dari dimensi iklim organisasi tergolong tinggi.

Dasar dalam mengelola dimensi iklim organisasi BKD Provinsi NTB dapat mengacu pada hasil uji signifikansinya, sebagai berikut.

Tabel 2.

Signifikansi Pengaruh Dimensi Iklim Organisasi terhadap Kinerja

\begin{tabular}{|c|l|c|c|c|c|}
\hline No. & \multicolumn{1}{|c|}{ Variabel } & $\begin{array}{c}\text { Koefisien } \\
\text { Jalur }\end{array}$ & thitung & t tabel & Kriteria \\
\hline 1. & $\begin{array}{l}\text { Lingkungan Fisik (X1) -> Sasaran } \\
\text { Kerja Pegawai (Y1) }\end{array}$ & 0,279 & 2,670 & 1,96 & $\mathrm{H}_{\mathrm{a}}$ diterima \\
\hline 2. & $\begin{array}{l}\text { Lingkungan Fisik (X1) -> Perilaku } \\
\text { Kerja Pegawai (Y2) }\end{array}$ & 0,153 & 1,382 & 1,96 & $\mathrm{H}_{\mathrm{a}}$ ditolak \\
\hline 3. & $\begin{array}{l}\text { Lingkungan Sosial (X2) -> Sasaran } \\
\text { Kerja Pegawai (Y1) }\end{array}$ & 0,319 & 3,013 & 1,96 & $\mathrm{H}_{\mathrm{a}}$ diterima \\
\hline 4. & $\begin{array}{l}\text { Lingkungan Sosial (X2) -> } \\
\text { Perilaku Kerja Pegawai (Y2) }\end{array}$ & 0,284 & 2,936 & 1,96 & $\mathrm{H}_{\mathrm{a}}$ diterima \\
\hline 5. & $\begin{array}{l}\text { Sistem Manajemen (X3) -> Sasaran } \\
\text { Kerja Pegawai (Y1) }\end{array}$ & 0,308 & 3,113 & 1,96 & $\mathrm{H}_{\mathrm{a}}$ diterima \\
\hline 6. & $\begin{array}{l}\text { Sistem Manajemen (X3) -> } \\
\text { Perilaku Kerja Pegawai (Y2) }\end{array}$ & 0,426 & 4,861 & 1,96 & $\mathrm{H}_{\mathrm{a}}$ diterima \\
\hline
\end{tabular}

Uji signifikansi di atas memberikan pembuktian bahwa hanya hipotesis kedua tidak terbukti. Artinya bahwa pengelolaan lingkungan fisik $\left(\mathrm{X}_{1}\right)$ tidak memberikan perubahan yang nyata atas perilaku kerja pegawai $\left(\mathrm{Y}_{2}\right)$ BKD Provinsi NTB. Adapun atas SKP terbukti bahwa dimensi lingkungan fisik memberikan pengaruh yang signifikan. Pengelolaan lingkungan sosial $\left(X_{2}\right)$ dan sistem manajemen $\left(X_{3}\right)$ ternyata memberikan pengaruh yang signifikan terhadap kinerja, baik melalui dimensi SKP dan PKP.

Kajian asosiasi dari dimensi iklim organisasi terhadap kinerja (dimensi SKP dan PKP) mempunyai dasar teori yang jelas. Hal tersebut juga menjadi persyaratan dalam analisis PLS, bahwa konteksnya adalah pengujian teori (konfirmasi teori bukan eksplorasi asosiasi antar variabel (Ghozali, 2008:18). Deninson (1996), Rorong (2016), Adi dan Soehari (2015) menyatakan bahwa lingkungan fisik berpengaruh terhadap kinerja, dalam konteks penelitian ini melalui SKP. Keberadaan kondisi kerja yang nyaman, fasilitas kerja yang memenuhi syarat kuantitas dan kesesuaian perkembangan teknologi akan mendukung pelaksnaaan pekerjaan tepat waktu, tepat kualitas, tepat alokasi waktu dan biaya. Fasilitas kerja yang tidak memadai akan menyebabkan pemborosan waktu, biaya dan kemungkinan hasil kerja yang tidak memenuhi standar. Hal ini memperjelas dan memperkuat temuan bahwa lingkungan fisik $\left(\mathrm{X}_{1}\right)$ berpengaruh signifikan terhadap SKP $\left(\mathrm{Y}_{1}\right)$.

Penelitian yang dilakukan bersifat spesifik, karena kinerja dirumuskan sesuai dengan kondisi empiris pengukuran kinerja PNS (PP No. 46 tahun 2011). Deninson (1996) memberikan pedoman bahwa lingkungan fisik berpengaruh terhadap kinerja, tetapi tidak terbukti melalui PKP $\left(\mathrm{Y}_{2}\right)$. PKP lebih bersifat perilaku dan kondisi psikologis pegawai yang bekerja dengan orientasi pelayanan, berintegritas, disiplin dan kemampuan bekerja sama. Variabel PKP lebih dapat digerakkan dengan aspek yang bersifat memberikan stimulan atas kondisi sosial dan psikologis pegawai, bukan wadah dalam bekerja.

Lingkungan sosial $\left(\mathrm{X}_{2}\right)$ berpengaruh signifikan terhadap kinerja, baik melalui SKP $\left(\mathrm{Y}_{1}\right)$ maupun PKP $\left(\mathrm{Y}_{2}\right)$. Harmonisasi hubungan dalam lingkungan internal organisasi memberikan implikasi pada kemampuannya menyelesaikan pekerjaan dan mendukung perilakunya dalam memberikan pelayanan, disiplin, integritas dan kerjasama. Tanpa hubungan yang harmonis, maka dipastikan perilaku kerja pegawai tidak akan disiplin, 


\section{Jurnal Magister Manajemen Unram Vol. 9, No 1. Maret 2020 NATIONALLY ACCREDITED JOURNAL - DECREE NO. 21/E/KPT/2018}

tidak akan mampu bekerjasama dengan rekan kerjanya. Lingkungan sosial yang harmonis akan mengarahkan pegawai bekerja dengan seluruh potensi yang dimiliki dan berperilaku sesuai dengan harapan untuk mengakumulasi kerja yang lebih baik.

Dimensi ketiga dari iklim organisasi berupa sistem manajemen $\left(X_{3}\right)$ terbukti berpengaruh signifikan terhadap kinerja melalui SKP $\left(\mathrm{Y}_{1}\right)$ dan PKP $\left(\mathrm{Y}_{2}\right)$. Perolehan alokasi sumber daya, imbalan, pengembangan karir mempunyai relevansi dengan pembuktian diri pegawai mampu menyelesaikan pekerjaan dengan kriteria yang ditetapkan organisasi, baik dari aspek kuantitas, kualitas, alokasi waktu dan biaya. Ketepatan kebijakan organisasi dalam sistem manajemen akan menguatkan pembuktian diri pegawai dalam menghasilkan kerja, bahkan berupaya melebihi standar yang ditetapkan oleh organisasi. Sisi lain, sistem manajemen juga berpengaruh terhadap perilaku kerjanya, karena dengan pelibatan dirinya sebagai pengambil keputusan dan individu yang ada dalam birokrasi, maka mewujudkan sikap dan perilaku kerjanya sebagai PNS.

Enam pembuktian hipotesis dalam penelitian ini memberikan penegasan bahwa bahwa 1) dimensi lingkungan fisik BKD Provinsi NTB berpengaruh signifikan terhadap kinerja pegawai hanya melalui sasaran kerja pegawai; 2) dimensi lingkungan sosial BKD Provinsi NTB berpengaruh signifikan terhadap kinerja pegawai, baik melalui peningkatan sasaran kerja pegawai dan perilaku kerja pegawai; serta 3) sistem manajemen BKD Provinsi NTB berpengaruh nyata terhadap kinerja pegawai melalui peningkatan pencapaian sasaran kerja pegawai dan perilaku kerjanya. Hasil penelitian ini memperkuat model Deninson (1996), bahkan dapat berkontribusi atas pengaruh langsungnya terhadap kinerja, bukan melalui motivasi.

Pengelolaan iklim organisasi berbasis tiga dimensi, yaitu lingkungan fisik, lingkungan sosial dan sistem manajemen BKD Provinsi NTB sangat perlu dilakukan, karena memberikan pengaruh yang berarti terhadap kinerja. Lingkungan fisik, lingkungan sosial dan sistem manajemen BKD Provinsi NTB memberikan pengaruh terhadap sasaran kerja pegawai 0,360 (36,00\%) dan terhadap perilaku kerja sebesar 0,350 (35,00\%). Tingkat pengaruh tersebut dapat dinyatakan cukup kuat, dilihat dari banyaknya faktor yang mempengaruhi kinerja pegawai. Satu sisi hanya perbaikan pada tiga dimensi dari iklim organisasi BKD Provinsi NTB dapat memberikan variasi naik turunnya kinerja pegawai, melalui sasaran kerja pegawai sebesar $36,00 \%$ dan melalui perilaku kerja pegawai sebesar $35,00 \%$.

Implikasi manajerial (pengelolaan organisasi) dapat ditegaskan bahwa pihak manajemen organisasi, khususnya di BKD Provinsi NTB sangat perlu memperhatikan perbaikan pada lingkungan fisik, lingkungan sosial dan sistem manajemen, karena dapat meningkatkan kinerja pegawai. Perbaikan pada lingkungan fisik, berupa perbaikan atas kenyamanan tempat kerja dengan memperhatikan pendingin atau kebersihan tempat kerja telah dapat meningkatkan pencapaian sasaran kerja pegawai. Pengelolaan lingkungan fisik organisasi tidak selalu membutuhkan anggaran yang besar, karena perbaikan atas kenyamanan tempat kerja saja telah mampu meningkatkan pencapaian sasaran kerja. Pada kurun waktu tertentu perlu juga dilakukan analisis kesesuaian dan kecukupan peralatan kerja yang dimiliki. Lingkungan fisik meningkatkan kinerja pegawai dari pencapaian sasaran kerja, bukan dari perbaikan perilaku kerjanya.

Dimensi iklim organisasi yang dapat diperhatikan adalah penciptaan kondisi yang harmonis antar pegawai. Perbaikan pada dimensi ini mempengaruhi kinerja, baik pada sasaran kerja dan perilaku kerja pegawai BKD Provinsi NTB. Perbaikan pada dimensi ini tidak membutuhkan anggaran besar, karena dapat dilakukan dengan menciptakan suasana hubungan harmonis antar pegawai, termasuk dengan atasan serta membangun nilai saling percaya dan saling mendukung antar pegawai.

jmm.unram.ac.id 


\section{Jurnal Magister Manajemen Unram Vol. 9, No 1. Maret 2020 NATIONALLY ACCREDITED JOURNAL - DECREE NO. 21/E/KPT/2018}

Pihak manajemen BKD Provinsi NTB juga dapat memperhatikan pengelolaan sistem manajemen, terkait dengan birokrasi, proses pengambilan keputusan, alokasi sumber daya, sistem imbalan dan pengembangan pegawai. Pengelolaan yang semakin baik atas dimensi sistem manajemen BKD Provinsi NTB memberikan dampak atas peningkatan kinerja, baik atas sasaran kerja pegawai dan perilaku kerja pegawainya.

\section{KESIMPULAN DAN SARAN}

Simpulan yang dapat dirumuskan adalah :

1. Lingkungan fisik berpengaruh positif signifikan terhadap sasaran kerja pegawai BKD Provinsi NTB. Perbaikan atas item-item lingkungan fisik dapat meningkatkan secara nyata atas pencapaian sasaran kerja pegawai BKD Provinsi NTB. Perbaikan dimensi lingkungan fisik BKD Provinsi NTB dapat meningkatkan kinerja melalui sasaran kerja pegawai.

2. Lingkungan fisik berpengaruh psoitif, namun tidak signifikan terhadap perilaku kerja pegawai BKD Provinsi NTB. Artinya pengelolaan atau perbaikan atas kondisi lingkungan fisik BKD Provinsi NTB tidak akan mempengaruhi kinerja melalui perilaku kerja pegawainya.

3. Lingkungan sosial berpengaruh positif signifikan terhadap sasaran kerja pegawai BKD provinsi NTB. Artinya perbaikan harmonisasi hubungan antar pegawai yang tercermin dari hubungan kerjasama, saling mendukung dalam kreativitas dan saling mempercayai meningkatkan kondisi lingkungan sosial pegawai BKD Provinsi NTB dapat meningkatkan kinerja melalui sasaran kerja pegawainya.

4. Lingkungan sosial BKD Provinsi NTB berpengaruh positif signifikan terhadap perilaku kerja pegawainya. Artinya pengelolaan harmonisasi hubungan antar pegawai di internal BKD Provinsi NTB dapat mengarahkan perilaku pegawai yang lebih berorientasi pada pelayanan, integritas, disiplin dan kerjasama antar pegawai.

5. Sistem manajemen BKD Provinsi NTB memberikan pengaruh positif signifikan terhadap sasaran kerja pegawai. Artinya perbaikan atas sistem manajemen di internal BKD Provinsi NTB akan secara nyata meningkatkan pencapaian sasaran kerja pegawainya.

Adapun sarannya adalah :

1. Bagi manajemen BKD Provinsi NTB telah menerapkan kebijakan atau sasaran kerja jangka pendek yang relevan dengan perbaikan kondisi lingkungan fisik dan lingkungan sosial, sehingga perlu diperkuat. Kebijakan tersebut berupa perbaikan kenyamanan lingkungan fisik dan perbaikan komunikasi. Sistem manajemen hendaknya mendapatkan perhatian dengan menerapkan sistem reward yang lebih baik, pengembangan karir dan alokasi sumber daya dengan berbasis proporsional dengan kinerja periode sebelumnya.

2. Para peneliti selanjutnya dapat mengembangkan model Deninson ini, dengan menyertakan variabel moderat. Hal ini disarankan, karena masih banyak variabel lain yang mempengaruhi kinerja melalui SKP dan PKP. 


\section{Jurnal Magister Manajemen Unram Vol. 9, No 1. Maret 2020 NATIONALLY ACCREDITED JOURNAL - DECREE NO. 21/E/KPT/2018}

\section{DAFTAR PUSTAKA}

2011. Peraturan Pemerintah No. 46 Tahun 2011 tentang Penilaian Prestasi Kerja Pegawai Negeri Sipil. Jakarta.

Adi, A.S.C., dan Soehari, T.D., 2015. Pengaruh Kepemimpinan, Lingkungan Kerja dan Kepuasan Kerja Terhadap Kinerja Karyawan PT. SIG. Jurnal Managerial. Vol. 9. No. 2. hal. 57-64.

Ahmad, Z., et.al. 2010. Organizational Climate (OC) as Employees' Satisfier: Empirical Evidence from Pharmaceutical Sector. International Journal of Business and Management. Vol. 5. No.10. p. 2014-222.

Ahmad, 2010. Pengaruh Iklim Organisasi Dan Motivasi Intrinsik Terhadap Kinerja Pegawai Dinas Pendidikan Pemuda Dan Olah Raga Kota Mataram. Jurnal Tesis Program Magister Manajemen Universitas Mataram. Mataram.

Arakal, T., dan Mampiliy, S.R., 2013. The Impact of Organisational Climate on Performance of Employees. Trends and Challenges in Global Business Management. p.235-238.

Aryansyah, I., dan Kusumaputri, E.S., 2013. Iklim Organisasi dan Kualitas Kehidupan Kerja Karyawan. Jurnal Humanitas Vol. X No.1 hal. 75-86.

Asi, S.P., 2013. Pengaruh Iklim Organisasi dan Burnout terhadap Kinerja Perawat RSUD dr. Doris Sylvanus Palangka Raya. Jurnal Aplikasi Manajemen. Vol. 11. No. 3. hal. 515-523.

Conbrink, A.J., 2004. The Validation Of An Organisational Climate Questionnaire In A Corporate Pharmacy Group. Disertation for Degree Master of Arts in Industrial Psychology at the North-West University.

Fauzan, R., dan Rahmadewi, S., 2013. Pengaruh Iklim Organisasi Dan Kepuasan Kerja Terhadap Kinerja Karyawan. Jurnal Eksos. Vol. IX No.3.. hal.135-152.

Ferdinand, A., 2003. Structural Equation Model Dalam Penelitian Manajemen. Semarang: BP. UNDIP.

Furnham, A., dan Goodstein, L.D., 1997. The Organizational Climate Questionnaire (OCQ). Jurnal Counsulting. Vol.2. p. 163-179.

Gathmyr, D., 2017. The Influence Of Climate Organization, Commitment Of Professional To The Performance Aviators Officer Air Squadron Airmen In The Air Force Base 31 Halim Perdanakusuma Jakarta. Jurnal Prodi Strategi Pertahanan Udara. Vol.3.No.2.hal. 1-28.

Ghozali, I., 2011. Structural Equation Modeling Metode Alternatif dengan Partial Least Square: PLS. Semarang: Badan Penerbit Universitas Diponegoro.

Gujarati, N.D dan Porter, C. D. 2010. Dasar-dasar Ekonometrika. Jakarta: Salemba Empat.

Handayani, W.N., dan Hati, S.W., 2018. Pengaruh Lingkungan Kerja Fisik Terhadap Produktivitas Kerja Karyawan Operator Bagian Produksipada Perusahaan Manufaktur Di PT ABC Batam. Jurnal Aplikasi Administrasi. Vol. 21. No. 1. hal. 9-30.

Hartanto, F.M., 2009, Paradigma Baru Manajemen Indonesia; Menciptakan Nilai dengan Bertumpu pada Kabajikan dan Potensi Insani, Bandung:PT. Integre Quadro.

Holloway, J.B., 2012. Leadership Behavior and Organizational Climate: An Empirical Study in a Non-profit Organization. Emerging Leadership Journeys. Vol. 5. No.1. p.9-35.

Khan, N.U., et.al., 2015. The Impact of Multiple Organizational Climates on Performance of Public Sector Organizations: Evidences from Pakistan. International Journal of Economics and Financial Issues. Vol. 5. p. 276-282.

Lalu Suparman, dkk., 2018. Analysis of the Leadership Influence on Organizational Climate, Organizational Commitment and Work Behavior of National Program for Urban Community Empowerment in Lombok. Journal of Business and Management (IOSR-JBM). Vol. 20. No.8. p. 49-64. 


\section{Jurnal Magister Manajemen Unram Vol. 9, No 1. Maret 2020 NATIONALLY ACCREDITED JOURNAL - DECREE NO. 21/E/KPT/2018}

Lee, D.Y., et.al. 2012. The Impact Of Employee's Perception Of Organizational Climate On Their Technology Acceptance Toward E-Learning In South Korea. An International Journal. Vol.4.No.3. p.359-378.

Mahadevan, A., dan Li, Y.P., 2017. A Study On The Impact Of Organisational Climate On Employee Performance In A Malaysian Consltancy. International Journal of Accounting $\mathcal{E}$ Business Management. Vol. 5. No.1. p.1-13.

Mahmudi, 2007, Manajemen Kinerja Sektor Publik, Yogyakarta:UPP, AMP YPKN.

Patterson, M.G., et.al., 2005. Validating The Organizational Climate Measure: Links To Managerial Practices,Productivity And Innovation. Journal of Organizational Behavior. Vol.26. p.379-408.

Putra, I.B.K., dan Rahyuda, A.G., 2015. Pengaruh Lingkungan Kerja Fisik dan Stres Kerja terhadap Kinerja Pegawai di UPT.. Pengujian Kendaraan Bermotor Dinas Perhubungan Kota Denpasar. Jurnal Manajemen UNUD. Vol. 4 No. 9.

Putter, L., 2010. The Relation Between Organizational Climate And Performance And An Investigation of The Antecedents of Organizational Climate. Delf University of Technology.

Riggle, R.J., 2007. The Impact Of Organizational Climate Variables Of Perceived Organizational Support, Workplace Isolation, And Ethical Climate On Salesperson Psychological And Behavioral Work Outcomes. University of South Florida.

Robbin, S.P., 2003, Perilaku Organisasi, Jilid 1 , PT. Prenhallindo, Penerjemah, Tim Indkes, Jakarta: PT. Indeks.

Robbins, P.S. dan Judge, A.T., 2008. Perilaku Organisasi. Jakarta: PT. Indeks.

Rorong, S.V., 2016. The Impact Of Physical Work Environment Toward Employee Performance At Pt. Bank Negara Indonesia Manado Regional Office. Jurnal EMBA. Vol. 4. No.1. hal. 441450 .

Rothmann, S., dan Combrink, J., 2004. The Validation Of An Organisational ClimateQuestionnadre In A Corporate Pharmacy Group. Dissertation. North-West University.

Samsudin, S., 2006. Manajemen Sumber Daya Manusia. Bandung: Pustaka Setia.

Sedarmayanti, 2007, Manajemen Sumber Daya Manusia, Reformasi Birokrasi dan Manajemen Pegawai Negeri Sipil, Bandung:PT.Refika Aditama.

Setiawan, K.C., 2015. Pengaruh Iklim Organisasi terhadap Kinerja Karyawan Level Pelaksana Di Divisi Operasi PT. Pusri Palembang. Jurnal Psikologi Islami Vol. 1. No.1. hal. 23-32.

Sihotang, A., Manajemen Sumber Daya Manusia. Jakarta: PT. Pradnya Paramita.

Simamora, H., 2004. Manajemen Sumber Daya Manusia. Yogyakarta: STIE YKPN.

Sofo, F., 2003. Perspektif, Peran dan Pilihan Praktis Pengembangan Sumber Daya Manusia. Surabaya: Ailangga University Press.

Sugiyono, 2005, Metode Penelitian Bisnis, Bandung:CV. Alfabeta.

Syahrum, A., dkk., 2016. Effect of Competence, Organizational Culture and Climate of Organization to the Organizational Commitment, Job Satisfaction and the Performance of Employees in the Scope of Makassar City Government. International Journal of Business and Management Invention. Vol. 5. No. 4. p.52-64.

Tantowi, R., dan Astuti, H.W., 2016. Pengaruh Iklim Organisasi Terhadap Kinerja Karyawan Pada PT. Bank Danamon Simpan Pinjam Unit Metro. Vol. 2. No.2. hal. 134-145.

Umar, H., 2008, Metode Penelitian untuk Skripsi dan Tesis Bisnis, Jakarta: Raja Wali Press.

Varsani, M., 2017. Innovative Productivity Linked To Perception Of Organisational Climate. Journal Grant. Vol.9.No.4. p. 71-76.

Widarjono, A. 2007. Ekonometrika: Teori dan Aplikasi untuk Ekonomi Bisnis. Yogyakarta: Ekonisia. 
Wirawan, 2007, Budaya dan Iklim Organisasi; Teori Aplikasi dan Penelitian, Jakarta:Salemba Empat.

Yadav, Y., et.al., 2016. Organizational Climate - A Study carried out in an Electronic Manufacturing Industry in Mysuru. International Research Journal of Engineering and Technology (IRJET). p. 168-174.

Zulkiram, dkk., 2013. Pengaruh Iklim Organisasi, Disiplin Kerja Dan Kompensasi Terhadap Kinerja Pegawai Serta Dampaknya Pada Kinerja Lembaga Pemasyarakatan Klas Iia Banda Aceh. Jurnal Manajemen Pascasarjana Universitas Syiah Kuala. Vol.2. No.1. hal.128137. 